DEVELOPMENT OF MANAGEMENT

AND ENTREPRENEURSHIP METHODS

ON TRANSPORT, № 4 (77), 2021
РОЗВИТОК МЕТОДІВ

УПРАВЛІННЯ ТА ГОСПОДАРЮВАННЯ

НА ТРАНСПОРТІ, № 4 (77), 2021
УДК 656.06

JEL D 20, L 39

DOI 10.31375/2226-1915-2021-4-32-47

\section{СУТНІСТЬ ТА ОРГАНІЗАЦІЯ ДІЯЛЬНОСТІ ІНСПЕКЦІЙНИХ ПІДПРИЕМСТВ НА МОРСЬКОМУ ТРАНСПОРТІ}

\section{А.К. Смаркалова}

викладач кафедри «Експлуатація портів і технологія вантажних робіт» antoninasmarkalova $@$ gmail.com ORCID https://orcid.org/0000-0002-8631-2915

Одеській національний морський університет, Одеса, Украӥна

Анотація. У статті розглянуто сферу інспекиійної діяльності на морському транспорті, як невід'ємну ланку системи ринкових відносин. Розглянуто історію та причини появи сфери інспекиійних послуг у прочесі здійснення міжнародної торгівлі та вивчено основні передумови, чинники та нормативно-правові засади до здійснення діяльності інспекиійними підприємствами. Визначено основні види інспекційних організацій, які надають свої послуги з безпосередньо якісної та/або кількісної екс-пертизи, конкретних об'єктів, предметів або явищ. Досліджено відмінності між інспекиійними підприємствами, відповідно до розробленої класифікаиії, в залежності від форм власності, специфіки послуг, які ними надаються та організаиії їх діяльності. Визначено необхідність та умови залучення незалежних інспекиійних організаціий до транспортного процесу. Розглянуто особливості інспекиійних послуг, що надають інспектори Клубів взаємного страхування, аварійні комісари та вантажні сюрвейєри. Визначено основних споживачів інспекиійних послуг серед учасників логістичного прочесу. Проаналізовано взаємозв'язки сюрвейєрських компаній з рештою учасників процесу купівліпродажу товарів. Виділено місие та роль незалежних сюрвейєрських компаній у схемі укладання зовнішньоторговельної угоди.

Ключові слова: інспекиійні організаиії, сюрвей, сюрвейєрська діяльність, Клуби взаємного страхування, аварійні комісари.

\section{(C) Смаркалова А.К., 2021}

УДК 656.06

JEL D 20, L 39

DOI 10.31375/2226-1915-2021-4-32-47

СУЩНОСТЬ

И ОРГАНИЗАЦИЯ ДЕЯТЕЛЬНОСТИ ИНСПЕКЦИОННЫХ ПРЕДПРИЯТИЙ НА МОРСКОМ ТРАНСПОРТЕ

А.К. Смаркалова

преподаватель кафедры

«Эксплуатация портов

и технология грузовых работ» antoninasmarkalova@gmail.com

ORCID https://orcid.org/0000-0002-8631-2915

Одесский наииональный

морской университет, Одеса, Украӥна

Аннотация. В статье рассмотрена сфера инспекичионной деятельности на морском транспорте, как неотъемлемое звено системы рыночных отношений. Рассмотрены история и причины появления сферы инспекционных услуг в процессе осуществления международной торговли и изучены основные предпосылки, факторы и нормативно-правовые основы для осуществления деятельности инспекиионными предприятиями. Определены основные виды инспекиионных организаиий, которые предоставляют свои услуги по непосредственно качественной и/или количественной экспертизе конкретных объектов, предметов или явлений. Исследованы различия между инспекционными предприятиями согласно разработанной классификации, в зависимости от форм собственности, специфики предоставляемых ими услуг и организации их деятельности. Определены необходимость и условия привлечения независимых инспекционных организаций $\kappa$ транспортному прочессу. Рассмотрены особенности инспекиионных услуг, предоставляемых инспекторами Клубов взаимного страхования, аварийными комиссарами и грузовыми сюрвейерами. Определены основные потребители инспекиионных услуг среди участников логистического прочесса. Проанализированы взаимосвязи сюрвейерских компаний с остальнымми участниками прочесса купли-продажи товаров. Выделены место и роль независимых сюрвейерских компаний в схеме заключения внешнеторгового соглашения.

Ключевые слова: инспекиионные организачии, сюрвей, сюрвейерская деятельность, Клубы взаимного страхования, аварийные комиссары. 
UDC 656.06

JEL D 20, L 39

DOI 10.31375/2226-1915-2021-4-32-47

\title{
NATURE AND ORGANIZATION OF ACTIVITIES OF INSPECTION BODIES ON MARINE TRANSPORT
}

\author{
Antonina Smarkalova \\ Lecturer of Department «Port Operations and Cargo Technologies» \\ antoninasmarkalova@gmail.com \\ ORCID https://orcid.org/0000-0002-8631-2915
}

Odessa National Maritime University, Odessa, Ukraine

\begin{abstract}
In the article, the nature and entity of inspection activities on marine transport are reviewed. Inspection organizations are divided by ownership. Different types of inspection bodies are looked into and specific scope of the inspection services they provide are elaborated. Consumers of inspection services, are identified, such as manufacturers, buyers, traders, shipowners, banks, etc. The reasons of a high rise in growth and spread of the inspection business are emphasized due to the increasing of competition and complete lack of trust in the maritime sector between all organizations and regulators inside the industry.

The necessity of involving an independent inspection organization into the transport process is investigated. The main prerequisites, factors and regulatory frameworks for the implementation of inspection activities and their extensive system of specializations are reviewed. Independent inspection services for qualitative and / or quantitative examinations of specific items, objects or occurrences, which facilitate the work and reduce risks of principals, are studied.

The features of inspection services provided are distinguished between inspectors of $P \& I$ Clubs, which represent associations that provide marine protection and indemnity liability cover for shipowners, loss adjusters, who serve as claims specialists and are appointed by insurance companies, and also independent cargo surveyors, who act as the third party and provide services for independent and impartial quantitative and qualitative inspection of various goods in accordance with modern international requirements. The relationship between independent surveying companies and the rest of the participants in the process of purchase and sale of goods was determined. Some of the most important usual assignments and activities of independent inspector at the transport services market are described and schematized. The place and role of independent inspection companies in the scheme of formatting, concluding and effecting of a foreign trade agreement are highlighted.
\end{abstract}

Keywords: inspection organizations, survey, surveying operations, P\&I clubs, loss adjusters.

Постановка проблеми. Інспекції, як специфічний вид послуг, затребуваний у процесі здійснення міжнародної торгівлі, на будь-якому із етапів логістичного процесу, розпочинаючи від виробництва продукту, під час перебування його на складі або транспортування.
Сфера інспектування у морській галузі налічує сотні років історії та розвивається як невід'ємна ланка системи ринкових відносин. Необхідність у залученні інспекційних організацій до транспортного процесу може виникати у будь-якого його учасника, приймаючи до уваги широкий спектр послуг, що можуть нада- 
ватись. Важливо відмітити, що до основних видів інспекційних послуг на морському транспорті відносяться не тільки інспекції транспортних засобів, а також і інспекції вантажів.

У свою чергу, не кожне інспекційне підприємство здатне надавати повний спектр послуг, які необхідні сторонам у процесі здійснення міжнародної торгівлі. До того ж, окрім специфіки надаваних послуг, на діяльність інспекційних організацій впливають, і самі споживачі інспекційних послуг, а також їх умови залучення до роботи.

Ринок інспекційних послуг в Україні насичений, а кількість компаній, що пропонують свої послуги в сфері інспектування, 3 кожним днем зростає. Кожна компанія, відповідно до іiі сутності, займає окреме місце у галузі та виконує свою роль у відносинах 3 іншими учасниками транспортного процесу.

Загалом, інспекційна діяльність все одно залишається невивченою сферою морської галузі. Крім того, на ринку інспекційних послуг виникає багато проблем різного характеру, у тому числі і тих, які пов'язані з відсутністю специфічної теоретичної бази, що і зумовлює актуальність цієї статті.

Огляд останніх досліджень та публікацій. Питанням діяльності інспекційних підприємств на морському транспорті займаються як іноземні, так і українські вчені. Основні аспекти сюрвейєрської діяльності в своїх працях розглядали А.Б. Ляшенко, О.А. Мошнянський, О.О. Гриценко [1], Б.С. Гуральник, С.С. Кубрін [2]. Практичні проблеми, що виникають при здійсненні інспекційної діяльності підіймали Б.Дж. ЛоуерХілл (Bryan J. Lower-Hill, 1999) [3], Ci. Дарем (C. Durham, 1988) [4], Г.П. Яковенко [5].

Питання відмінностей між інспекційними організаціями порушував у своїх наукових працях B.I. Снопков [6; 7]. Основні види морського сюрвея та послуги, що надаються сюрвейєрськими компаніями досліджувались також I. М. Петровим [8]. Проте, при вивченні деяких 3 питань, що виникають при наданні інспекційних послуг, недостатньо уваги приділялося розгляду самих інспекційних організацій, передумовам їх створення та умовам їх існування. У наукових працях які присвячені сюрвею відсутня класифікація інспекційних підприємств та бракує чіткої ідентифікації організації їх діяльності.

Задачі дослідження. Метою даної статті $€$ визначення сутності, специфіки та організації діяльності інспекційних підприємств (надання інспекційних послуг) у морській галузі.

Основний матеріал дослідження. Термін «інспектування» на англійську мову перекладається як «survey», відповідно сюрвейєр - людина, яка виконує роботу з інспектування, що робить доцільним прирівняти поняття «інспектор» до поняття «сюрвейєр», а термін «інспекційна діяльність» до «сюрвейєрської діяльності».

Отож, сюрвейєр - це інспектор, незалежний професіонал високої кваліфікації, який надає послуги 3 незалежного та неупередженого кількісного та якісного інспектування різних товарів відповідно до сучасних між- 
DEVELOPMENT OF MANAGEMENT

AND ENTREPRENEURSHIP METHODS ON TRANSPORT, № 4 (77), 2021
РОЗВИТОК МЕТОДІВ

УПРАВЛІННЯ ТА ГОСПОДАРЮВАННЯ

НА ТРАНСПОРТІ, № 4 (77), 2021 народних вимог [9]. Відповідно, сюрвей, як вид діяльності - це комплекс послуг різної спрямованості якісної та/або кількісної експертизи конкретних об'єктів, предметів або явищ, що надаються незацікавленою стороною. Деякі науковці вважають, що окрім цього, сюрвей, як вид діяльності, може включати у себе також оцінку потенційних ризиків та розробки відповідних рекомендацій щодо їх запобігання [10].

Появу явища «сюрвей» помилково пов'язують виключно 3 поширенням страхування перевезень вантажів морем та обмежують діяльність сюрвейєрів лише оглядом товарів та/ або майна, яке приймається на страхування, або розслідуванням настання аварійного випадку. Насправді ж, необхідність в третій, незалежній стороні - спостерігачі, яка могла визначати якість або вимірювати кількість вантажу, виникла при розповсюджені документарних операцій в міжнародних розрахунках.

Як відомо, до першої половини XIX століття, товари по світу перевозилися суднами великих торгівельних домів i компаній. Це були досить відомі організації, такі як, наприклад, Британська Ост-Індійська компанія, Голландська Ост-Індійська компанія, Російсько-Американська компанія. Місцеві представники цих компаній продавали привезені товари, такі як ай, мідь, срібло, текстиль, бавовна, шовк, кераміка, прянощі і за рахунок виторгу купували товари для імпорту.

Починаючи 3 середини XIX століття, більшість державних торгівельних монополій були ліквідовані і світові товарні ринки стали більш відкритими. Контакти між продав- цями і покупцями стали більш знеособленими. Часовий розрив між укладанням контракту, постачанням i оплатою став настільки великий, що сторонам угоди стало необхідно пересвідчуватись в тому, що їх діловий партнер на іншому кінці світу в змозі виконати свої зобов'язання. Саме в цей момент з'явився механізм документарних банківських розрахунків-платежів, що здійснюються 3 наданням документів, таких як коносаменти, накладні або страхові поліси. Використання такого механізму розрахунків до певної міри могло гарантувати продавцю, що він отримає плату за свій товар за встановленою ціною i у встановлений термін, а покупцю, в свою чергу, гарантувалося своєчасне отримання товару в відповідній якості та кількості. Так почали виникати інспекційні й експертні компаніі.

Відлік існування незалежного інспектування як окремого виду діяльності в транспортному процесі розпочинається у 1878 році, у Франціï, коли Генрі Голдстак вперше розпочав здійснювати перевірку зерна, що прибувало до порту Руан, виявляючи втрати в обсязі вантажу результаті усадки та крадіжок під час транзиту [11].

Іноземні джерела відносять подальший розквіт інспекційної індустрії в країнах ЄС та США до факту повної відсутності довіри у морській галузі між усіма галузевими організаціями та регулюючими органами [12].

3 отримання Україною незалежності, цей вид діяльності став прогресивно розвиватися як невід'ємна ланка системи ринкових відносин і у нашій державі. 
У процесі довгого становлення сюрвею як виду діяльності розвилась розгалужена система спеціалізацій у інспектуванні.

Першочергово, інспекційні організації поділяються за формами власності на дві великі категорії (рис. 1).

1. Державні організації (або ті, що діють від імені та за дорученням Держави) що займаються експертною та інспекційною діяльністю. В приклад можна привести наступні організації:

- Служба капітана морського порту, яка входить до складу Державної служби морського та річкового транспорту України. Служба є самостійним структурним підрозділом Морської адміністрації, що забезпечує державний нагляд (контроль) за безпекою мореплавства, в тому числі у морських терміналах, розташованих у межах територій та акваторій, відокремлених від основної території та акваторії відповідного морського порту [13];

- Класифікаційні товариства, основними цілями яких $є$ забезпечення безпеки людського життя на морі, забезпечення безпечного плавання суден, забезпечення безпечного перевезення вантажів на морі і внутрішніх водних шляхах та запобігання забрудненню навколишнього середовища. Відповідно до Положення про Регістр судноплавства України та статті 22 Кодексу торговельного мореплавства України, статей 26 і 29 Закону України «Про транспорт», в Україні відповідальними органами 3 питань технічного нагляду є Регістр судноплавства України, з питань судноплавного нагляду - Держфлотінспекція.

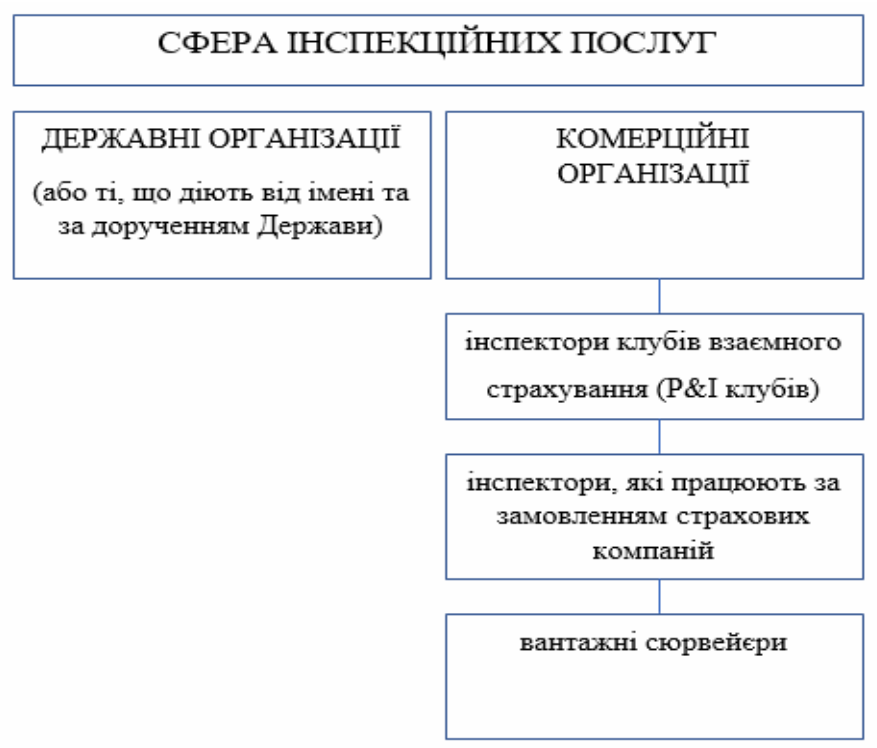

Рис. 1. Сфера інспекиійних послуг

Джерело: власна розробка автора 
Класифікаційні товариства видають на судна, які здійснюють закордонні рейси, свідоцтва, передбачені міжнародними договорами 3 питань торговельного мореплавства. Також у межах компетенції Класифікаційних товариств $\epsilon$ експертиза технічного стану суден або інших об'єктів нагляду згідно 3 нормативними документами та інші послуги із класифікації та сертифікації систем якості і виробів промисловості України, а також закордонних виробів, за погодженням 3 Держстандартом та відповідно до вимог Української державної системи сертифікації продукції (УкрСЕПРО) [14];

- Торгово-промислова палата України, завданням якої є організація взаємодії між суб'єктами підприємницької діяльності, координація їх взаємовідносин з державою в особі іiі органів. Торгово-промислова палата уповноважена видавати сертифікати про походження товарів, засвідчувати обставини форс-мажору, а також торгівельні і портові звичаї, заведені в Україні [15];

2. Приватні - комерційні інспекційні компанії, які надають послуги усім учасникам процесу купівлі-продажу на будь-якому проміжку логістичного ланцюга. Такі організації доцільніше класифікувати відповідно до споживачів послуг.

В основному, на практиці, комерційні компанії, що надають інспекційні послуги, поділяються на три наступні групи:

- інспектори клубів взаємного страхування (Р\&I клубів);

- інспектори, що працюють за замовленням страхових компаній;

- вантажні інспектори - сюрвейєри.

Відповідно, область послуг таких незалежних інспекційних компаній досить широка, тож для зручності, пї можна умовно розділити на наступні основні категорії (рис. 2):
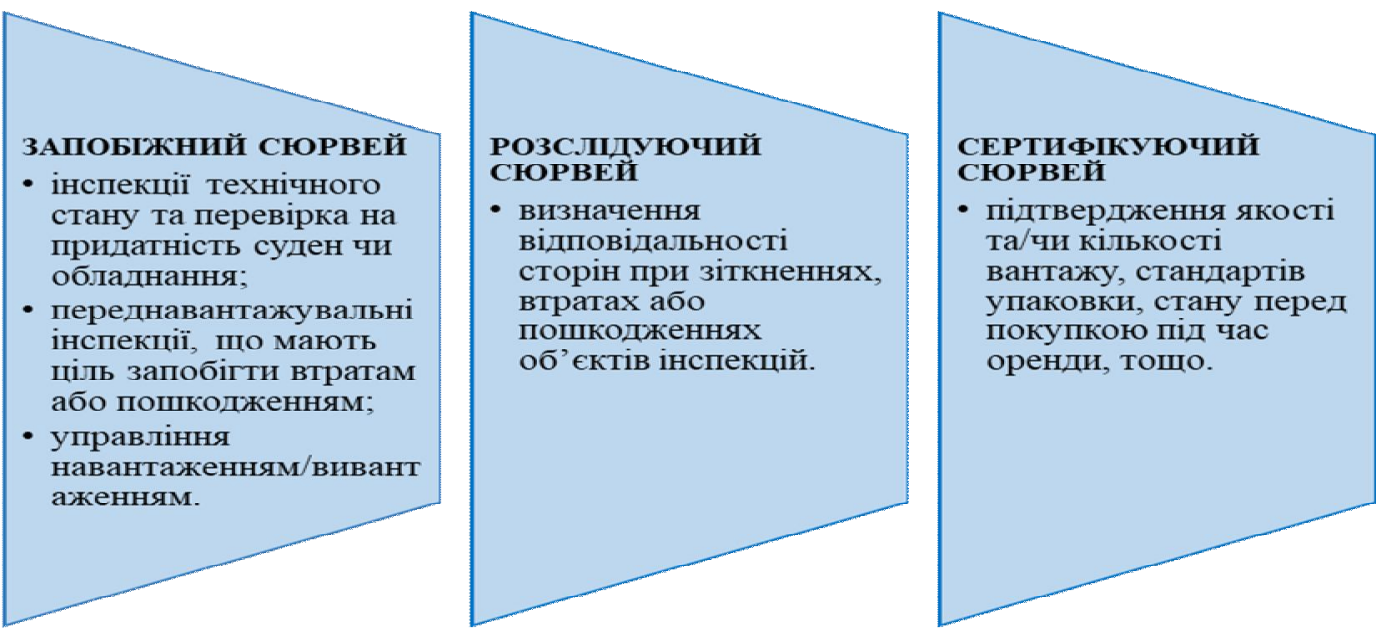

Рис. 2. Категорії послуг незалежних інспекиійних компаній

Джерело: сформовано автором на основі [1] 
DEVELOPMENT OF MANAGEMENT

AND ENTREPRENEURSHIP METHODS ON TRANSPORT, № 4 (77), 2021
РОЗВИТОК МЕТОДІВ

УПРАВЛІННЯ ТА ГОСПОДАРЮВАННЯ

НА ТРАНСПОРТІ, № 4 (77), 2021
Клуби взаємного страхування (P\&I club - protection and indemnity insurance) - це асоціації по захисту інтересів і взаємному страхуванню судновласників [16].

Судновласник, який має намір застрахувати своє судно, зазвичай стурбований двома аспектами фізичним ушкодженням судна і відповідальністю, яка витікає 3 факту володіння судном та роботи судна. Перший $з$ них покривається страховими полісами «Корпус» $\mathrm{i}$ «Машина». Відповідальність та ризики іншого роду традиційні страхові компанії не страхують, саме ними і займаються клуби P \& I. Наприклад, типове покриття P \& I може включати сторонні ризики перевізника щодо шкоди, заподіяної вантажу під час перевезення, ризики війни, ризики екологічної шкоди, включаючи розливи нафти та забруднення. Така система страхування вважається найбільш економічно ефективною та надійною світовою системою забезпечення морського страхування цивільної відповідальності.

На сьогоднішній день, в світі існує близько 70 клубів взаємного страхування.

До специфіки діяльності інспекторів для клубів взаємного страхування зазвичай відносяться наступні послуги:

- огляд та перевірка стану суден - кореспондентів. Такі інспекції мають назву «safety inspections», тобто перевірки безпеки. За результатами таких оглядів інспектор клубу взаємного страхування зазвичай видає звіт «Звіт про інспекцію судна» (Ship Inspection Report). Періодичність таких перевірок зазвичай становить 1 раз на рік та триває близько 8 годин. Результати такої перевірки впливають на річний страховий внесок судновласника.

- надання необхідної допомоги капітанам суден-кореспондентів;

- представлення інтересів судновласника та його клубу в вантажних претензійних актах.

Також, на практиці, до специфічних видів робот що виконують інспектори Р \& I відносяться, наприклад, збір доказових документів та супровід на лікування постраждалих під час рейсу моряків.

Зазвичай, P \& I клуби мають в своїх штатах декілька інспекторів, але, найчастіше, використовують місцевих сюрвейєрів.

В Україні найбільшими сюрвейєрами P \& I клубів можна виділити компанії - DIAS Marine Consultancy, ENMAS, CIS Pandi Services, SMC та інші.

Інспектори, які працюють за замовленням страхових компаній носять назву аварійних комісарів. Взагалі, існування аварійних комісарів як незалежних експертів, а не штатних працівників страхових компаній $є$ досить новим явищем в господарській діяльності України, запозиченим з досвіду зарубіжних країн. Підставою для діяльності таких інспекторів є настання страхового випадку.

Зазвичай, в обов'язки аварійних комісарів входить проведення експертизи та розслідування, пошук причин страхових випадків, збір фактів, документів та навіть розрахунок збитків. На підставі проведеного дослідження i зібраних документів аварійний комісар складає аварійний 
сертифікат - документ, в якому зазначаються обставини i причини настання страхового випадку та розмір заподіяної шкоди.

Також, такі інспектори залучаються страховими компаніями при необхідності повного огляду об'єкта майбутнього страхування. Як правило, інспектор перевіряє стан об'єкту, відповідність його стандартам та нормам, проводить огляд систем безпеки, протипожежних систем, тощо.

Діяльність аварійних комісарів регулюється Постановою Кабінету Міністрів «Про затвердження Типового положення про організацію діяльності аварійних комісарів» [17].

Збільшення обсягів світової торгівлі, розширення їі географії та глобалізація призвели до збільшення числа організацій третьої групи, а саме вантажних сюрвейєрів.

Основними принципами існування комерційних інспекційних організацій що займаються вантажним сюрвейєм є їх незалежність та чесність. Ці принципи набуваються за умови управління без будь-якого комерційного, фінансового або іншого тиску.

Також, важливо відмітити, що невід'ємними чинником успішної діяльності вантажних сюрвейєрів $\epsilon$ дотримання усіх вимог у галузі законодавства, екології, охорони та безпеки праці, а також клієнтоорієнтованість. Серед споживачів послуг вантажних сюрвейєрів можна виявити наступні категорії:

- виробники та покупці на товарно-сировинних ринках, агропромислових ринках, ринках хімічної, легкої та важкої промисловості;
- трейдери;

- банки;

- експедитори або агенти;

- судновласники, суднобудівники та верфі;

- заводи;

- інші інспекційні компанії та лабораторії, страхові компанії, P\&I клуби;

- консультанти 3 питань довкілля;

- регулюючі органи та державні служби.

Зазвичай незалежні інспекційні компанії мають штат працівників вантажних сюрвейєрів, які залучаються до роботи, в залежності від свого профілю. Залучення сюрвейєра на роботу має назву номінація.

Так як важливою частиною роботи інспекційних компаній $є$ саме надання послуг 3 якісних інспекцій, важливим підрозділом будь-якої сюрвейєрської компанії $\epsilon$ хімічна науково-випробувальна лабораторія, яка здатна надавати клієнтам повний спектр аналітичних послуг.

Залучення до роботи незалежних вантажних інспекторів відбувається, як правило, за наступними причинами:

- використання для здійснення угоди купівлі-продажу банківського акредитиву. Відповідно до цієї схеми оплати, банку покупця, для переведення коштів продавцю, необхідне підтвердження виконання угоди. Серед інших, банк запитує і свідчення третьої незалежної сторони щодо відповідності вантажу заявленій угодою якості та заявленій кількості;

- використання стандартних договорів купівлі-продажу міжнародних асоціацій, таких як ГАФТА 
DEVELOPMENT OF MANAGEMENT

AND ENTREPRENEURSHIP METHODS ON TRANSPORT, № 4 (77), 2021
РОЗВИТОК МЕТОДІВ

УПРАВЛІННЯ ТА ГОСПОДАРЮВАННЯ

НА ТРАНСПОРТІ, № 4 (77), 2021
(GAFTA) чи ФОСФА (FOSFA). Відповідно до таких контрактів, виконання робіт 3 контролю кількості та якості товару може виконуватися лише незалежними інспекторами та їх лабораторіями 3 відповідних реєстрів самих асоціацій;

- бажання сторін зовнішньоторговельної угоди максимально захистити себе від ризиків за пошкодження чи втрату товару, відповідно до розподілу витрат та ризиків по умовам поставок Інкотермс.

На практиці, в Україні, при розгляданні договорів купівлі-продажу, найбільш широко зустрічається умова поставок Інкотермс «FOB» (Free on Board), тобто «вільно на борту», за яким встановлюється, зобов'язання продавців доставити товар в обумовлений порт, на борт судна, яке номінували покупці. Коли товар знаходиться на борту судна, відбувається перехід ризиків за пошкодження чи втрату товару 3 продавців на покупців. 3 цього моменту витрати на товар несуть покупці. Саме у ситуаціях переходу відповідальності між сторонами, принципали звертаються до сюрвейєра для забезпечення себе істинними обставинами та експертними висновками щодо ситуацій, що можуть виникати протягом усього процесу виконання умов угоди.

- деякі особливості митного оформлення, при яких митниця потребує підтвердження відповідності заявлених якісних характеристик вантажу фактичним, а також дотримання формальностей, безпосередньо пов'язаних із здійсненням контролю безпеки.

Загалом, купівля-продаж товарів у системі міжнародної торгівлі - процес складний, та може включати в себе усі перелічені вище ситуації. Умовно, стандартну схему укладання угоди та залучення до іï виконання третіх сторін можна представити у наступній схемі (рис. 3).

Насамперед, укладання договору купівлі-продажу проходить безпосередньо між трейдерським відділами покупця i продавця. Під час укладання угоди, сторонами прописуються усі обов'язкові умови, які покладаються на покупця та продавця.

До таких умов відносяться, насамперед, вид товару, якість, кількість товару, пункт призначення, період здійснення відправки, ціна та умови здійснення оплати, тощо. Важливою умовою $є$ також умова поставки - Інкотермс, якою визначаються обов'язки, витрати та ризики всіх сторін. Залежно від обраного базису, визначаються обов'язки сторін організувати мінімальне страхове покриття у разі втрати чи пошкодження товарів під час транспортування.

Усі прописані умови, відповідно, покладають на кожну зі сторін угоди зобов'язання.

Підписаний контракт трейдерські відділи передають до виконання відділам виконання контрактів, які, відповідно до зобов'язань, мають організувати весь процес транспортування.

По-перше, обидві сторони процесу звертаються до своїх банків задля врегулювання процесу оплати угоди. Найчастіше, засобом фінансування договору, сторонами обирається документарний розрахунок акредитив, за аналогією 3 банківською гарантією. 

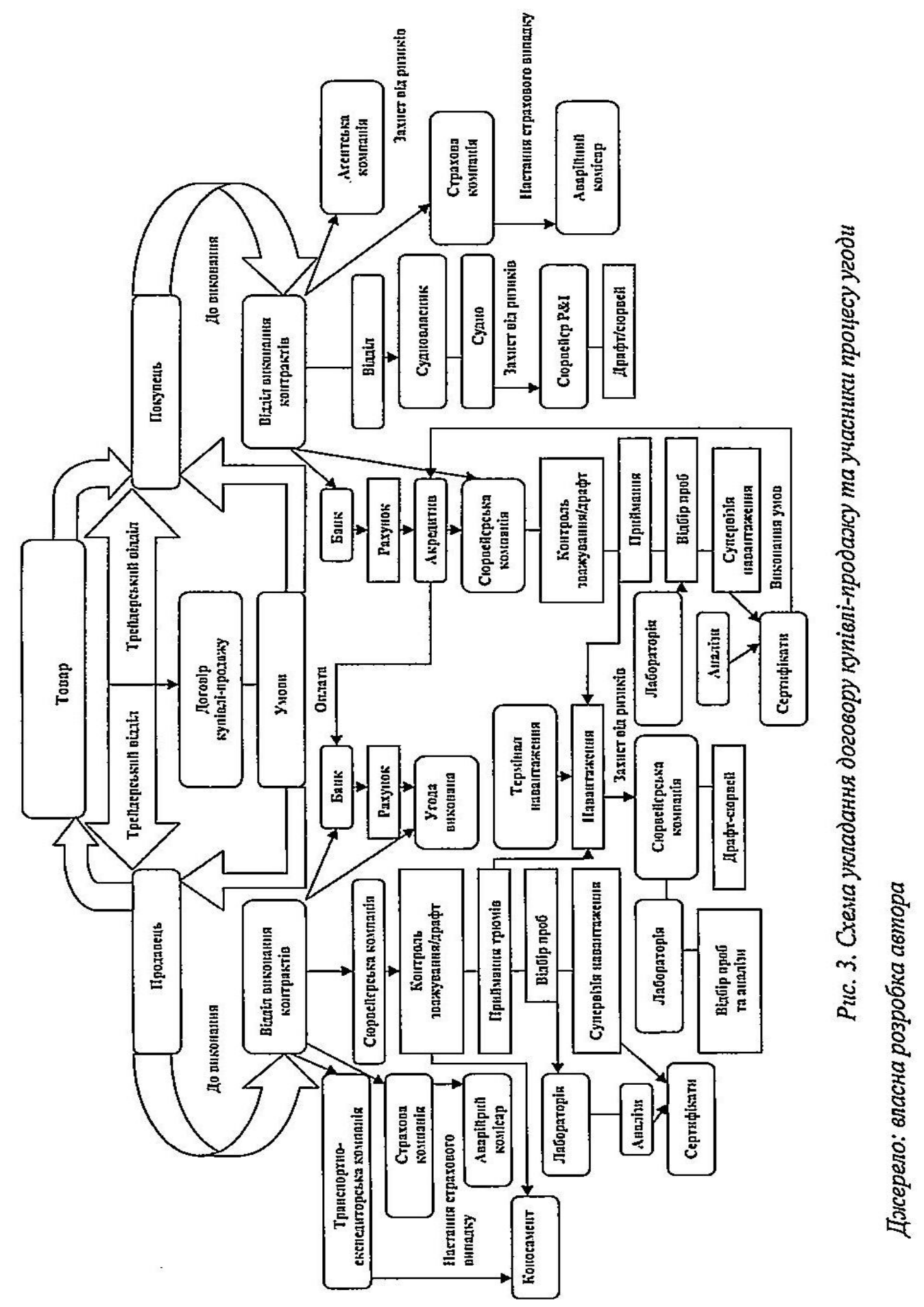
DEVELOPMENT OF MANAGEMENT

AND ENTREPRENEURSHIP METHODS ON TRANSPORT, № 4 (77), 2021
РОЗВИТОК МЕТОДІВ

УПРАВЛІННЯ ТА ГОСПОДАРЮВАННЯ

НА ТРАНСПОРТІ, № 4 (77), 2021
Для здійснення угоди такого виду, покупець звертається до банку, у якому відкриває рахунок та робить внесок у розмірі оплати товару, згідно договору. Банк, у свою чергу, випускає акредитив з умовами, до виконання яких гроші на рахунку покупця «блокуються».

Відділ виконання контрактів покупця, виконуючи зобов'язання, передає усю необхідну інформацію відділу фрахтування, який здійснює фрахтування судна за заявленими параметрами. Відділ виконання контрактів, у свою чергу, залучає до роботи агентську компанію.

Відділ виконання контрактів продавця обирає термінал та наймає транспортно-експедиторську компанію.

Для виконання умов по Інкотермс, обидві сторони звертаються до страхових компаній.

Залучення до роботи незалежних інспекційних організацій прописується у договорі окремим пунктом, тож обидві сторони, в залежності від необхідності, запрошують до роботи сюрвейєрську компанію.

Важливо відзначити, що сюрвейєрська організація, у загальних випадках, не має права працювати більш ніж на одну сторону торгівельної угоди чи транспортного процесу. Виключення складають ситуації коли сторони заздалегідь вносять виключення до угоди, домовляючись між собою щодо номінації однієї і тієї ж незалежної інспекційної компанії. Найчастіше таке відбувається у випадках, коли обидві сторони мають намір скоротити витрати, та розділяють бюджет на залучення сюрвейєрів порівну.
Усі обов'язки вантажного сюрвейєра та перелік робот до виконання, зазвичай, окреслюються клієнтом на момент номінації, відповідно до ії причини.

Насамперед, до початку навантаження, незалежний інспектор виконує роботу з визначення чистоти та придатності вантажних приміщень судна під навантаження. Сюрвейєр проводить ретельний візуальний огляд кожного вантажного приміщення судна, а також їх механізмів закриття на предмет відповідності вимогам для перевезення. Залежно від виду вантажу розрізняються i вимоги, що пред'являються до вантажних приміщень. Однак, у всіх випадках перед навантаженням вантажні приміщення повинні бути: вантажу;

- без залишків попереднього

- сухі і чисті;

- без іржі що відшаровується і старої фарби;

- без сторонніх запахів;

- без сторонніх предметів.

Для певних видів вантажів можуть пред'являтися особливі вимоги до вантажних приміщень. Для багатьох видів вантажів мають значення характеристики попереднього вантажу, тобто вантажу, який зберігався або перевозився в даному вантажному приміщенні. Крім того додаткові вимоги до вантажних приміщень можуть пред'являтися і в залежності від класу небезпеки вантажу.

Відповідна робота проводиться для уникнення можливого забруднення чи псування товару. Важливо відзначити, що «прийняття» сюрвейєрами вантажних приміщень під навантаження, тобто підтвердження 
DEVELOPMENT OF MANAGEMENT

AND ENTREPRENEURSHIP METHODS ON TRANSPORT, № 4 (77), 2021
РОЗВИТОК МЕТОДІВ

УПРАВЛІННЯ ТА ГОСПОДАРЮВАННЯ

НА ТРАНСПОРТІ, № 4 (77), 2021 їх відповідності вимогам, є відправною точкою до початку процесу навантажування.

Паралельно інспекції вантажних приміщень проводиться робота щодо визначення кількості вантажу, навантаженого на борт судна. Існує кілька методів контролю кількості вантажу, основними 3 яких можна виділити метод «зважування», який передбачає безперервний контроль сюрвейєром зважування вхідного вантажу у автомобілях чи вагонах на ваговій, а також метод «драфт-сюрвею», тобто визначення кількості навантаженого вантажу по осіданню судна. Кожен 3 методів використовується в залежності від виду вантажу, який навантажують. У разі визначення кількості вантажу на борт судна методом драфт-сюрвею, навантаження не може початися до того, як сюрвейєр визначить усі необхідні виміри при порожніх вантажних приміщеннях. Даний вид роботи зветься «початковий драфт-сюрвей».

Далі, в процесі навантаження, сюрвейєр проводить контроль вантажних операцій, а саме безперервне спостереження за вантажними операціями та зовнішнім станом вантажу. Такий вид інспекції носить назву «супервізія». Важливо зауважити, що супервізія повинна здійснюватися безперервно протягом усього навантаження, 3 точки максимально наближеної до місця навантаження 3 дотриманням усіх необхідних заходів безпеки. Таким чином, у випадку, якщо в процесі навантаження буде виявлено непридатний для транспортування товар, усі сторони будуть сповіщені, а працівники терміналу проведуть необхідні зачисні операції. Слід зазначити, що сюрвейєр не має права зупиняти процес навантаження, а виконує роль лише незалежного спостерігача, який передає факти своєму замовнику, який, своєю чергою, має право вимагати зупинити навантаження до усунення усіх невідповідностей.

У різних інспекційних компаніях використовується свій підхід до організації безперервного спостереження за вантажними роботами. Правила проведення супервізії регламентується виключно відповідними внутрішніми інструкціями та розпорядженнями сюрвейєрської компанії.

Ще однією 3 важливих функцій сюрвейєра на борту судна $\epsilon$ відбір проб. В даний час існує безліч різноманітних методик відбору проб різних видів вантажів. Дані правила викладені у матеріалах ГОСТ, ДСТУ, ISO тощо. Завдання сюрвейєра часто полягає у визначенні методики, потрібної для відбору проб у кожному конкретному випадку, та узгодженні цього питання із замовником. Найчастіше метою відбору проб $\epsilon$ отримання представницької проби, тобто проби на підставі аналізу якої можна судити про якісні характеристики всієї партії товару. Таку пробу також називають композитною.

Проби що були відібрані відправляють на аналізи до хімічної лабораторії. У лабораторії перевіряється якість вантажу на відповідність заявленій специфікації. Результати аналізів використовуються надалі для видання сюрвейєрських сертифікатів. Фінальною стадією роботи незалежного сюрвейєра $\epsilon$ видання сертифікатів згідно вимога акриди- 
тива. Серед базових сертифікатів, які сюрвейєр видає на офіційному бланку та завіряє своїм підписом і мокрою печаткою, можна виділити сертифікат чистоти вантажних приміщень, сертифікат ваги або сертифікат драфтсюрвею та сертифікат якості. В усіх сертифікатах обов'язково вказується порт навантаження та порт вивантаження, найменування товару, загальна вага партії вантажу, визначена сюрвейєром, та дати, коли проводилася інспекція.

Зазначені сертифікати передаються принципалу, який, в свою чергу, використовує ці документи як підтвердження виконання усіх умов угоди в повній мірі.

Важливо відмітити що термінал, як і судновласник, мають право номінувати власну незалежну сюрвейєрську компанію на проведення робіт 3 визначення кількості завантаженого вантажу, а також, у разі потреби, залучити хімічну лабораторію для здійснення відбору проб хімікамитехнологами та проведення набораторних випробувань. Таким чином, у разі виникнення надалі спірних ситуацій, Термінал та Судновласник матимуть можливість мінімізувати ризики фінансової відповідальності та захистити власні інтереси.

Висновки. Отже, як підсумок, можна зробити висновок що інспек- ційна діяльність $є$ суттєвою та необхідною частиною морської галузі, а саме будівництва, експлуатації та ремонту флоту, страхування та торгівлі, а також в галузі виробництва. Майже кожен етап логістичного шляху будь-якого товару, від місця виробництва до кінцевого споживача, контролюється тим чи іншим чином інспекторами різної кваліфікації. Огляди та інспекції необхідні за різноманітними причинами, від регуляції обов'язкового залучення інспекційних органів державними законами, до бажання сторін транспортного процесу захистити можливі ризики своєї діяльності, у тому числі і фінансові.

Таким чином, у даній статті було виконано класифікацію інспекційних підприємств, відповідно до форм власності, видів діяльності, що вони надають, а також за споживачами інспекційних послуг. Окремо було розглянуто історію та передумови появи сюрвейєрського бізнесу. Також, була сформована система взаємозв'язків учасників міжнародної торгівлі на прикладі процесу виконання угоди купівлі-продажу 3 виділенням місця та ролі у цій схемі сюрвейєрських компаній, та було виділено основні види послуг, що ними надаються.

\section{СПИСОК ЛІТЕРАТУРИ}

1. Навчальні матеріали для курсів підвищення кваліфікації вантажних сюрвейсрів / О.Б. Ляшенко, О.О. Гриценко, О.О. Мошнянський та ін. Одеса: Одеський державний морський університет, 2001. $180 \mathrm{c.}$

2. Гуральник Б.С., Кубрін С.С. Сюрвейєрська справа: навчальний посібник. Калінінград: Фабрика друку, 2008. 136 с. 
3. Bryan J. Lower-Hill. Lloyds Survey Handbook / Bryan J. Lower-Hill. London: Informa UK Ltd, 1999. 347 c.

4. Durham C.F. Marine Surveys. London: Fairplay publication, 1988.

5. Яковенко Г.П., Яковенко І.Г., Яковенко Д.І. Деякі суттєві подробииі драфт-сюрвею. К.: Простір, 2011. 39 с.

6. Снопков B.I. Посібник із проведення сюрвейєрських робіт на транспорті. СПб., РФ: Мир и семья, 2003. 650 с.

7. Снопков В.І. Кодекс незалежних сюрвейєрів. СПб., РФ: Мир и семья, 2000. $500 \mathrm{c.}$

8. Петров І.М. Роль та місие сюрвейєра в сервісних ергатичних системах на морському транспорті // Матеріали науково-технічної конференції «Морський та річковий флот: експлуатачія і ремонт», 2015. № 2403. C. $146-150$

9. Корнієиь Т.С., Смаркалова А.К. Практика надання незалежних інспекиійних послуг при організації контейнерних перевезень соняшникового шроту // Вісник Одеського національного морського університету. Одеса: OHMУ, 2019. № 59. C. 155-165

10. Журавін С. Сюрвей як новий ступінь у системі ризик-менеджменту об'єктів нерухомості // Вісник Київського начіонального університету iм. Тараса Шевченка. Серія: Економіка 133. 2012. URL: https:// cyberleninka.ru/article/n/syurvey-kak-novaya-stupen-v-sisteme-risk-menedzhmenta-obektov-nedvizhimosti

11. Лідерство та інноваџї̈ з 1878 року. Історія Виникнення СЖC. URL: https://www.sgsgroup.com.ua/-/media/global/documents/brochures/sgs-grouphistory-ru.pdf.

12. Knapp S. Analysis of the Maritime Inspection Regimes-Are ships overinspected. 2006. URL: https://repub.eur.nl/pub/7895/EI\%20Report\%20200630.pdf.

13. Положення про капітана морського порту та службу капітана морськоzo nopmy. 2019. URL: https://zakon.rada.gov.ua/laws/show/z0632-13\#Text.

14. Про вдосконалення технічного, класифікаиійного і судноплавного нагляду на морському і річковому транспорті. 2013. URL: https://ips.ligazakon. net/document/KP980814? an $=15366$.

15. Закон Украӥни про торгово-промислові палати в Україні. 2020. URL: https://zakon.rada.gov.ua/laws/show/671/97-\%D0\%92\%D0\%A0\#Text.

16. Адамов А.С. Взаємне страхування судновласників. Досвід європейських країн // Актуальні проблеми держави і права. 2010. № 310

17. Про затвердження Типового положення про організацію діяльності аварійних комісарів. 2020. URL: https://zakon.rada.gov.ua/laws/show/8-98$\% D 0 \% B F \# T$ Text. 


\section{REFERENCES}

1. Liashenko, A.B., Hrytsenko, A.A., Moshnianskyj, A.A. \& oth. (2001). Uchebnye materyaly dlia kursov povyshenyia kvalyfykatsyy hruzovykh siurvejerov [Training materials for refresher courses for cargo surveyors]. Odesa: Odesskyj hosudarstvennyj morskoj unyversytet. [in Russian].

2. Hural'nyk, B.S. \& Kubrin, S.S. (2008). Siurvejiers'ka sprava: navchal'nyj posibnyk [Surveyor business]. Kalininhrad: Fabryka pechati, 136 p. [in Russian].

3. Bryan, J. Lower-Hill. (1999). Lloyds Survey Handbook. Lower-Hill. London: Informa UK Ltd, $347 \mathrm{p}$.

4. Durham C. F. (1988). Marine Surveys. Durham. London: Fairplay publication. [in English].

5. Yakovenko, H. P., Yakovenko, I. H. \& Yakovenko, D. I. (2011). Deiaki suttievi podrobytsi draft siurveiu [A few essential details of the draft survey]. Kyiv: Prostir, 39 p. [in Russian].

6. Snopkov, V.I. (2003). Posibnyk iz provedennia siurvejiers'kykh robit na transporti [A guide to conducting inspection work on transport]. SaintPetersburg, RF: Myr y sem'ia, 650 p. [in Russian].

7. Snopkov, V. I. (2000). Kodeks nezalezhnykh siurveieriv [Code of Independent Surveyors]. Saint-Petersburg, RF: Myr y sem'ia, 500 p. [in Russian].

8. Petrov, I.M. (2015). Rol' ta mistse siurvejiera $v$ servisnykh erhatychnykh systemakh na mors'komu transporti [Role and position of the surveyor in service ergatic systems of maritime transport]. Materialy naukovo-tekhnichnoi konferentsii «Mors'kyj ta richkovyj flot: ekspluatatsiia i remont»-Work materials of the scientific and technical conference «Marine and river fleet: operation and repairs». № 2403. P. 146-150. [in Russian].

9. Korniiets', T. Ye. \& Smarkalova, A. K. (2019). Praktyka nadannia nezalezhnykh inspektsijnykh posluh pry orhanizatsii kontejnernykh perevezen' soniashnykovoho shrotu [Practice of providing independent inspection services in process oforganisation of sunflowerseed meal transportations in containers]. Visnyk Odes'koho natsional'noho mors'koho universytetu - Bulletin of the Odessa National Maritime University. №59. P. 155-165. [in Russian].

10. Zhuravin, S. (2012) Siurvej iak novyj stupin' u systemi ryzyk-menedzhmentu ob'iektiv nerukhomosti [Survey as a new stage in the real estate risk management system]. Visnyk Kyivs'koho natsional'noho universytetu im. Tarasa Shevchenka - Bulletin of Taras Shevchenko National University of Kyiv]. Seriia: Ekonomika 133. Retrieved from: https://cyberleninka.rul article/n/syurvey-kak-novaya-stupen-v-sisteme-risk-menedzhmenta-obektovnedvizhimosti [in Russian].

11. Liderstvo ta innovatsii z 1878 roku. Istoriia Vynyknennia SZhS [Leadership and innovation since 1878. History of SGSJ. Retrieved from: https:// www.sgsgroup.com.ua/-/media/global/documents/brochures/sgs-group-historyru.pdf. [in Russian]. 
12. Knapp, S. \& Franses, P. H. (2006). Analysis of the Maritime Inspection Regimes-Are ships over-inspected. Retrieved from: https://repub.eur.nl/ pub/7895/EI\%20Report\%202006-30.pdf.

13. Polozhennia pro kapitana mors'koho portu ta sluzhbu kapitana mors'koho portu [Regulations on the seaport Captain and the Service of the seaport Captain]. (2019). Retrieved from: https://zakon.rada.gov.ua/laws/show/z063213\#Text. [in Ukrainian].

14. Pro vdoskonalennia tekhnichnoho, klasyfikatsijnoho i sudnoplavnoho nahliadu na mors'komu i richkovomu transporti [On the technical, classification and shipping supervision of sea and river transport improvement]. (2013). Retrieved from: https://ips.ligazakon.net/document/KP980814?an=15366. [in Ukrainian].

15. Zakon Ukrayny (2020). Pro torhovo-promyslovi palaty v Ukraini [Law on Ukrainian Chamber of Commerce and Industry]. Retrieved from: https:// zakon.rada.gov.ua/laws/show/671/97-\%D0\%92\%D0\%A0\#Text. in Ukrainian].

16. Adamov, A.S. (2010). Vzaiemne strakhuvannia sudnovlasnykiv. Dosvid ievropejs'kykh krain [Mutual insurance of shipowners. European countries experience]. Aktual'ni problemy derzhavy i prava-Current issues of the State and law]. №310. [in Ukrainian].

17. Pro zatverdzhennia Typovoho polozhennia pro orhanizatsiiu diial'nosti avarijnykh komisariv [On authorization of Model provision for loss adjuster activity organization]. (2020). Retrieved from: https://zakon.rada.gov.ual laws/show/8-98-\%D0\%BF\#Text. [in Ukrainian].

Стаття надійшла до редакиії 06.12.2021

Посилання на статтю: Смаркалова А.К. Сутність та організація діяльності інспекційних підприємств на морському транспорту // Розвиток методів управління та господарювання на транспорті: Зб. наук. праць, 2021. № 4 (77). C. 32-47. DOI 10.31375/22261915-2021-4-32-47.

Article received 06.12.2021

Reference a JournalArtic: Smarkalova Antonina. (2021). Nature and organization of activities of inspection bodies on marine transport // Development of management and entrepreneurship methods on transport. 4, 32-47. DOI 10.31375/2226-1915-2021-4-32-47. 